\title{
Natural resources as a factor socioeconomic development: The case northeastern Montenegro
}

\author{
Goran Rajović ${ }^{1}$, Jelisavka Bulatović \\ ${ }^{1}$ Street Vojvode Stepe 252, Belgrade, Serbia \\ ${ }^{2}$ College of Textile Design, Technology and Management Street Starine Novaka 20, Belgrade, Serbia
}

\section{Email address:}

dkgoran.rajovic@gmail.com(G. Rajović), jelisavka.bulatovic@gmail.com(J. Bulatović)

\section{To cite this article:}

Goran Rajović, Jelisavka Bulatović. Natural Resources as a Factor Socioeconomic Development: The Case Northeastern Montenegro. Journal of Energy and Natural Resources. Vol. 2, No. 2, 2013, pp. 7-20. doi: 10.11648/j.jenr.20130202.11

\begin{abstract}
The paper discusses the natural resources of the northeastern of Montenegro as a factor of socio-economic development. Based on the properties of relief, we have selected three relatively homogeneous regions for economic development. Area sub region alluvial plains of rivers, river terraces, lake sediments Berane, Andrijevica and Polimlja Valley has the most favorable conditions for intensive agricultural production, summer tourism, construction and transport development. Diversity and complementarily of water resources is the main characteristic of the considered region, which is of particular importance for the future economic development. In the water resources, we looked at the possibilities of exploiting hydropower, water supply of population and industry, agriculture water supply. Thanks to the geological structure of the valley Berane there are significant reserves of brown coal and lignite (total reserves are 176.231.197 tons). Program development and production of coal in the valley Berane would cause intense regrouping and integration of industrial enterprises and caused the need for capacity expansion (Beran Village, Dolac). In the region, appear to ore metals: lead, zinc, copper, iron and pyrite. From non-metallic mineral resources, occupy their presence and reservoir construction materials: gravel, sand and decorative stone. Agricultural land is an important part of the natural wealth of the region. In the period 1964-2005 in the agricultural land there was a change in the way of exploitation to reduce the area under fields and gardens and pastures and increased the area under orchards and meadows.
\end{abstract}

Keywords: Northeastern Montenegro, Morphological Units, Water Resources, Mineral Resources, Agricultural Lands, Forests

\section{Introduction}

Northeastern Montenegro is a geographical unit, which includes the basin Lima in Montenegro, whose total area is $2.557 \mathrm{~km}^{2}$. Subject region with around $1.304 .1 \mathrm{~km}^{2}$ or about $51 \%$ of the total surface of the catchment in are Republic. Northeastern territory of Montenegro includes three municipalities: Berane, Andrijevica and Plav, with an area of $1.486 \mathrm{~km}^{2}$, which is on the 2003 census, 54.658 people lived or $36,8 \mathrm{in} / \mathrm{km}^{2}$. Natural resources as a factor of socio-economic development of the region were not investigating. So that our research records based on similar research Pavlović et al (2009), pointed to the forefront several obvious socio-economic problems:

1. First, because of geopolitical and economic crisis, the region is up to the Second World War was one of the most economically underdeveloped regions of the former Yugoslavia,
2. Second, only since the sixties of the twentieth century, there was a greater degree of valorization of the natural resources of the region, which led to a rapid economic development,

3. Third, the disintegration of the Federal Republic of Yugoslavia or the State Union of Serbia and Montenegro, and the border region receives a peripheral position in Montenegro, which in even more negative impact on economic trends.

Results of the survey were using to determine the author of those natural resources can cause faster economic trends in the region and to provide uniform spatial-functional development. Northeastern Montenegro has minerals, forests, waterpower and arable land, but they are not properly used. That was causing by unfavorable geographical and historical conditions in which the economy of the region has evolved. Given the natural resources, the holder of the economic development in the region, should be agriculture and tourism. Because not only 
agriculture and tourism to economic development through are its function with this development, but also their transformation into modern forms of economic development itself represents.

\section{Research Methodology}

Geographical study of natural resources has so far devoted little attention. Activities in this area are describing as partial consideration of this issue at some conferences and publications in the field of economy, tourism, biology, urban planning.... This research aims to meet the professional and the public with the natural resources of northeastern Montenegro, in the geographical context of their exploitation and use. Objective of this study it was possible to realize the combined use of different research methods. The core of the methodological procedure used in this paper makes geographic (spatial) method. Specifically, in terms of administrative and territorial affiliation, northeastern Montenegro includes three municipalities: Berane, Andrijevica and Plav. Application of statistical methods was necessary to define the quality characteristics of quantitative research. Permeated through the entire text of the analytical method and, thanks to which we are able to recognize, define and quantify the potential economic and social constraints of natural resources in terms of socio-economic development. Since work has essentially synthetic character, used the results published in the international literature. Among them this time emphasize this: Gylfason (2001), Ploeg (2001), Albrecht (2004), Hopwood and Mellor and O'Brien (2005), Rajović (2007a), Barbier (2007), Arezki and Ploeg (2011).

\section{Analysis and Discussion}

\subsection{Morphology and Opportunities and Economic Valorization}

The relief of the region is an important factor in economic development. According to the economic importance of the northeastern Montenegro, distinguish the two major morphological groups: Lim valley and mountainous area. For ease of determining morph metric relief benefits, primarily the impact of morph metric traits on agriculture, tourism and construction in the region hypsometric emphasize three areas: lower, middle and upper. In are lower hypsometric areas in terms of economic development. Spotlight area sub region alluvial plains of rivers, river terraces, lake sediments Berane, Andrijevica and Polimlja basin (A), which includes the area sub region of Plav-Gusinje Basin (B) and area sub region, which includes high-low regions mountainous areas of low relief and high-mountain relief of $948 \mathrm{~m}$ el to $1.100 \mathrm{~m}$ el (C).

I Area (A) sub region alluvial plains of rivers, river terraces, lake sediments Berane, Andrijevica and Polimlja basin (Figure 1) has the most favorable conditions for intensive agricultural production, summer tourism, construction and transport development. These are areas with a slope of up to $3^{\circ}$ and underexposed exposures. Length of the growing season with $\mathrm{Td} \geq 10^{\circ} \mathrm{C}$ is greater than 150 days and the sum of active temperatures of $\mathrm{Td} \geq$ $10^{\circ} \mathrm{C}$ higher than $2100^{\circ} \mathrm{C}$, allow the variety of plant vegetables. However, low values of relative humidity during April (62\%) increases the risk of spring frost and dew, and make these areas less favorable for fruit production. Adverse climatic characteristics are associated with a small amount of rainfall during July and August. In summer, (July and August) monthly mean relative humidity in the afternoon $(14 \mathrm{~h})$ is below $45 \%$. This low value of saturation of air is with water vapor, a very negative impact on agricultural crops. Large amplitude fluctuations of groundwater in alluvial deposits and the growing use of these waters makes it difficult for irrigation during the summer period. Therefore, the further back from the riverbed increases the depth of underground aquifers and less irrigation. Summer low flow, lack of access to coast, distance from the riverbed, are reducing the possibility of using river water for irrigation. For the alluvial flat alluvial are rivers connected with the land, which was the most important aspect of the production for possible cultivation of most crops. The river terraces as the dominant soil types of various production values, there are eutric camisoles, vertisols, pseudogley and amphigley. According to the natural advantages river alluvial plains and river terraces are suitable for intensive agriculture, particularly crop production (Rajović, 2009). This sub area is very important for the class trip, a certain summer tourist season and has characteristics of a distinct seasonal occurrence due to climate, or rather the air temperature. Average air temperature in the area during July and August is around $18^{\circ} \mathrm{C}$, and mean air temperature over $20^{\circ} \mathrm{C}$, it cannot taken as an absolute rule. First, the local population acclimated to river water temperature are conditions corresponding to an average value equal to or greater than $15^{\circ} \mathrm{C}$. Season bathing tourism and recreation at appropriate points may last from 30 to 90 days. This fact cannot ignored no matter what it is that the temperature conditions of a relatively modest measures conducive to the development of swimming, and therefore dismissed the coastal population and recreational functions. In relation to the recreational use of available resources of the area value assessment can do in terms of benefits of rowing sports, especially kayaking and canoe. The development of these activities strengthened by almost guaranteed a sufficient amount of water flowing in Lima, but the average decline (Murino - Andrijevica overall fall 75 feet, Andrijevica Berane $85 \mathrm{~m}$ ). At the same profile is registered and mean annual discharge of water, which meets the kayaking as one of the aspects of sports and recreational activities. Mountain water flows in what one of Lim ((except in the sector through Berane Basin) can use for kayaking and canoe. Rowing, sailing, kayaking, walking and hiking tourism are possible on the rivers of this district (Rajović, 2010). 


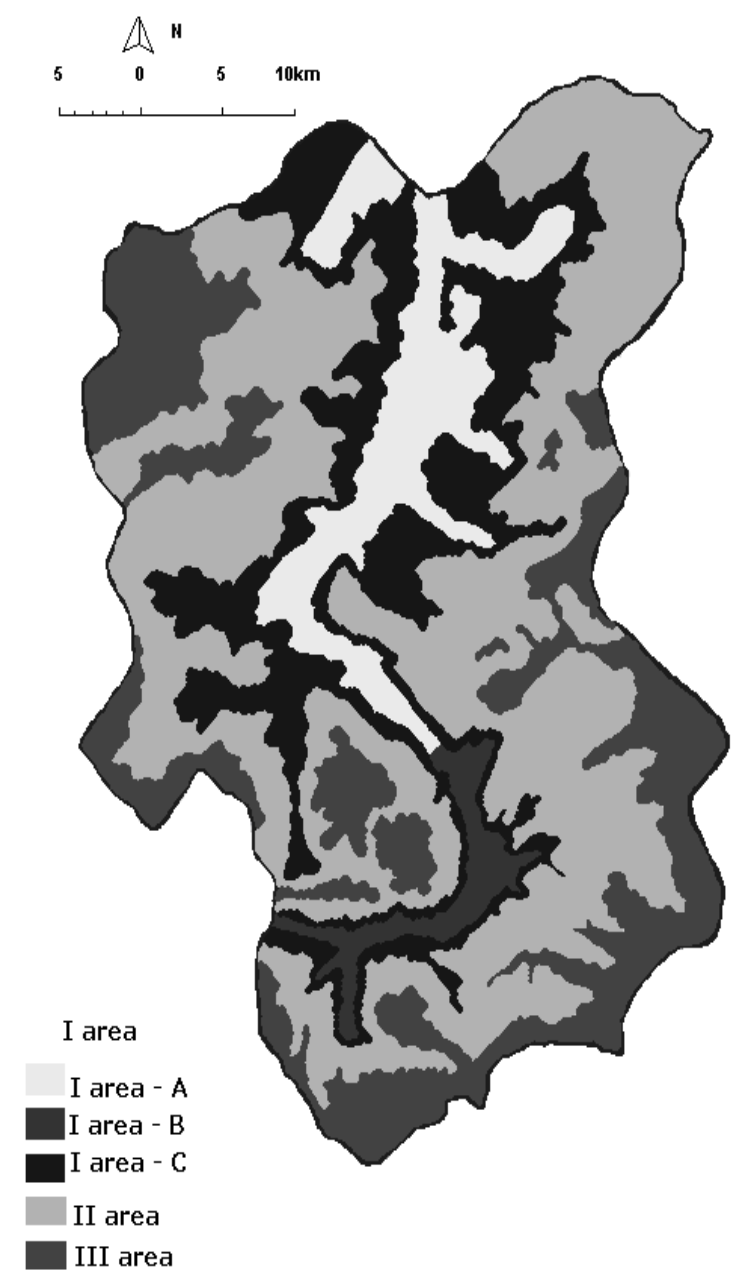

Figure 1. Morphological conditions of northeastern Montenegro according to the degree benefits of natural conditions development and collocation economy

Despite favorable conditions for development of agriculture and tourism are this spatial entity characterized by the favorable conditions for development of construction and transport. Any form of development (settlement, infrastructure, industrial facilities...) Indicates the specific is requirements in relation to certain morph metric characteristics. Morph metric requirements for construction, we have defined over from the construction of settlements and roads. The construction of the village is very small gradients (up to $1^{\circ}$ ) are not optimal, because the removal of atmospheric and water channel requires the formation of slope. However, since this region dominated by gradients of $1-3^{\circ}$, unexposed surface, good structure height (height ratio as an indicator of energy efficiency infrastructure, and express transport accessibility in relation to overcoming height differences) and the construction season lasts about 260 days, we have very good conditions for the construction of settlements and roads. Compared to the corresponding properties of climate, mean annual air temperature around $80-10^{\circ} \mathrm{C}$, relative humidity below $75 \%$ make this area suitable for habitation and livelihood of the population. Eating on development traffic characterized primarily for the winter half year. With regard to mean maximum thickness of snow along the route of the main roads in the valley of Lima does not exceed $50 \mathrm{~cm}$ in January, when the largest amount of snow and the number of days with snowfall lasting from October to May (when the snow melts already in contact with the ground), this area has good conditions for the flow of road traffic. Considered a whole has the capacity for industrial development because of lake sediments Berane lowland reservoirs are lignite and brown coal, and the river are the locality river Trebačka amount of building stone in the bed of the river Lim deposits of gravel and sand ( Rajović and Bulatović, 2012 a).

I Area sub region that includes Plav-Gusinje Basin (B) (Figure 1) have similar features as the previous agro climatic area sub region. It is characterizing by an inclination of $0-3^{\circ}$, and the unexposed southern exposure, altitudes up to $948 \mathrm{~m}$ evolution. The dominant soil type is fluvisol, locally present district cambisoles, eutric camisoles, podzol, planohistol (Lake Plav). Different shades of brown forest allow fruit production. This area belongs to the second class of so-called very favorable land for agricultural production. Length of growing season with $\mathrm{Td} \geq 10^{\circ} \mathrm{C}$ over 140 days and the sum of active temperature $\mathrm{Td} \geq 10^{\circ} \mathrm{C}$ is about $1200^{\circ} \mathrm{C}$, allow the cultivation of vegetable crops. In summer, (July and August) monthly mean relative humidity in the afternoon (14 h) was $46 \%$ below the already low value of saturation of air with water vapor, a very negative impact on agricultural crops. This allows the area and the development of summer tourism. Mean air temperatures during July and August is around $17^{\circ} \mathrm{C}$, relative humidity is about $66 \%$, and the water temperature about $16^{\circ} \mathrm{C}$. Swimming season lasts about 45 days. A sufficient amount of water flowing in Lima and the average decline in Plav Murino $(87 \mathrm{~m})$, mean annual water discharge (Lim at the Plav is $17,8 \mathrm{~m}^{3} / \mathrm{s}$ ) meet the needs of canoeing. Rowing, sailing, walking, underwater sports and fishing are possible in the Plav Lake. In addition, there are solid opportunities for the development of some sports and recreational activities during the winter season. Us then be influenced by negative values of temperature (which takes about 30-60 days), which would surface, except for some parts of Plav Lake, should be used as a natural ice rink with a previously detailed observation and studious appearance, thickness, quality and capacity of ice as hydrological phenomena present during the winter tourist season. As regards the construction and transport the region from the standpoint of urban building belongs to the class III suitable terrain (due no exposure and vertical belt $(948 \mathrm{~m})$ in length no period with frost (124 days)) and class II the point the construction of transport infrastructure (for vertical belt ). This sub area can be difficult to characterize performance of road transport; the mean maximum thickness of snow along the route of the main roads can reach $131 \mathrm{~cm}$. The thickness of snow cover can be very difficult obstacle to traffic, especially on windy passes and villages, where the wind 
forms a high snowdrifts that existing machinery can break a long time.

Area sub region high-mountain regions of low relief and low-medium landscape mountainous terrain up to $1.100 \mathrm{~m}$ above sea level (C) (Figure 1) characterized by mild forms of relief and side slopes of $6^{\circ}$ to $9^{\circ}$, greater depth of land covers (luvisols, vertisols, eutric camisols, districts cambisol, sometimes represented rendzina), relief forms are relatively favorable for agricultural production. The land is suitable for the production of various agricultural crops, orchards, and above $1000 \mathrm{~m}$ as is mainly woodland (beechfir forests, oak woods and forests of black and white pine), pastures and meadows. Bases Balja, the area around the rural settlements in the valley of the river Kralje Kraštica, Trešnjevik (relief and slope of the form $\left(3^{\circ}-9^{\circ}\right)$ ), are favorable for the production of certain fruits and vegetables. They represent the following area districts cambisol, iatric camisoles, rankers, colluvial soil et al. Dulipolje the settlements around Zlorecica, which flows into rivers Perućica and Kutska (slope $3^{\circ}-6^{\circ}$ ), good production potential of land (marsh gluey soil, eutric camisols, rendzina, districts camisoles, land, meadow), suitable for growing various crops, plants such as alder, field ash, oak, birch, and various types of forests (beech, oak, pine...). Kutski river valley of the river can seen as favorable for the production of certain crops (barley, oats, and corn) and fruit production, from the mouth to the settlement Zlorečica and Cecuni. Further to the source of the geomorphologic features, which make up the system on a particular area are not favorable for agricultural production but mostly there are pastures, meadows and forests (Rajović and Bulatović, $2012 \mathrm{~b}$ ). Areas on the left side of Lima from the expansion of Luge until Pepić (inclination of $3^{\circ}-6^{\circ}$ ) with the land (eutric camisols, colluvial soil, vertisols, amphigley land) are suitable for the production of vegetable crops, cultivation of meadows and forests. Areas on the right side of Lima, which include base Rasojevića head, Javorišta, Grahova, Koradzinog hill, Prijedola part between the mouth of the river Piščevske (slope $6^{\circ}-9^{\circ}$ and $12^{\circ}$ ) with the dominant land and districts and eutric cambisols, are relatively favorable for agricultural production. Rural areas of the territory above the valley of Plav-Gusinje of $948 \mathrm{~m}$ evolution to $1.100 \mathrm{~m}$ above the sea level mainly characterized by slopes of $12^{\circ}$ to $20^{\circ}$, with the dominant land: calcocambisol, podzol, brunipodzol, rankers, a sporadically occurring eutric and distric cambisoles. Valley of grasshoppers and Bilećko streams, rivers and Jasenička of the Novšić and rivers Velika, as well as part of the left and right side Vrulje are mostly inclined to $9^{\circ}-12^{\circ}$ can be used for agricultural production, while other parts are mostly forest land (forests of spruce, fir, and pine, oak). Mean air temperature in the course of the growing the region of the period about $12^{\circ} \mathrm{C}$, relative humidity of $68 \%$, and the length of the growing season with $\mathrm{Td} \geq 10^{\circ} \mathrm{C}$ for 130 days and the sum of active temperatures $1800^{\circ} \mathrm{C}$ allows growing of certain vegetable crops. From the standpoint of tourism, this is not the region attractive because of summer and winter holidays are no conditions. An interesting detail can be sulfuric water in the village of Kralje (see Rajović and Bulatović, 2013 a; Rajović and Bulatović, 2013 b). It can be developed or transitional excursion tourism. From the point of building roads and settlements, this region a Class III benefits (due to adverse vertical belt and the northern exposure). The region has opportunities for industry development; in Zagorje coal deposits are located, and the stand Zabrdje deposits of lead and zinc deposits Đulići marble.

II Area - is relating to the belt of 1100-1700 m above sea level, locally cut by deep river valleys cut into. This spatial unit characterized mainly with severe forms of the relief angle $12^{\circ}-20^{\circ}$. This region has rolled land cover, with the dominant land: rendzina, podsol, calc-camisoles calkocambisol, calkomenasol, rankers, and in places and districts camisoles suggesting that the predominantly grassland and forest vegetation (forest pine, spruce, beech, oak, fir). This relief unit is suitable for cattle breeding. Length of growing season with $\mathrm{Td} \geq 10^{\circ} \mathrm{C}$ from 91 to 130 days, with the sum of active temperature $\mathrm{Td} \geq 10^{\circ} \mathrm{C}$ to $1600^{\circ} \mathrm{C}$ to $2300^{\circ} \mathrm{C}$, the mean air temperature in the vegetation period is $9,5^{\circ} \mathrm{C}-12^{\circ} \mathrm{C}$ ( Rajović, 2012). Given that, for each food crop biologically determined minimum, the area near the river valleys (for example, Kutski River or at the foot of the Vlahova and Javorišta) it is possible to grow certain crops (wheat, barley, oats, peas, beans, and rye), orchards and grasslands (dominated eutric camisols and rendzina). From the standpoint of tourism, this area provides opportunities for the development of health and sports and recreational tourism. Moderately and slightly favorable for the development of winter tourism, which provides spaces: Bjelasice, Komova, Cmiljevice, Kofiljače. Average amount of precipitation (snow) from $101 \mathrm{~cm}$ to $130 \mathrm{~cm}$. Slopes are mostly from $12^{\circ}-20^{\circ}$ and the altitude belt above $1.300 \mathrm{~m}$ above sea level considered relatively favorable in terms of alpine lake disciplines. Great Šiško and Bukumirsko Lake provide opportunities for the development of picnic and summer tourism, as the summer air temperature of $14^{\circ}-15^{\circ} \mathrm{C}$ and the water temperature to $20^{\circ} \mathrm{C}$. In winter the lake under the ice and can be used as a natural ice rink with the previous detailed inspection. Given the presence of mineral deposits (lead, zinc, iron, pyrite), provides the foundation for industrial development. Construction season is from 230 to 250 days, but for certain work (e.g. work with concrete), this period coincides with the length of the free period without freezing temperatures, ranging from 67 to 117 days. The absolute amount of snow in this region may be greater than $200 \mathrm{~cm}$, which is a serious obstacle to the flow of traffic. In this area, there are numerous mountain pastures. During the winter and summer but here come a large number of climbers from various countries. They are as attractive characteristic of this region and provide a basis for further development of sports, mountain and hunting tourism, as well as the development of ecological tourism. 


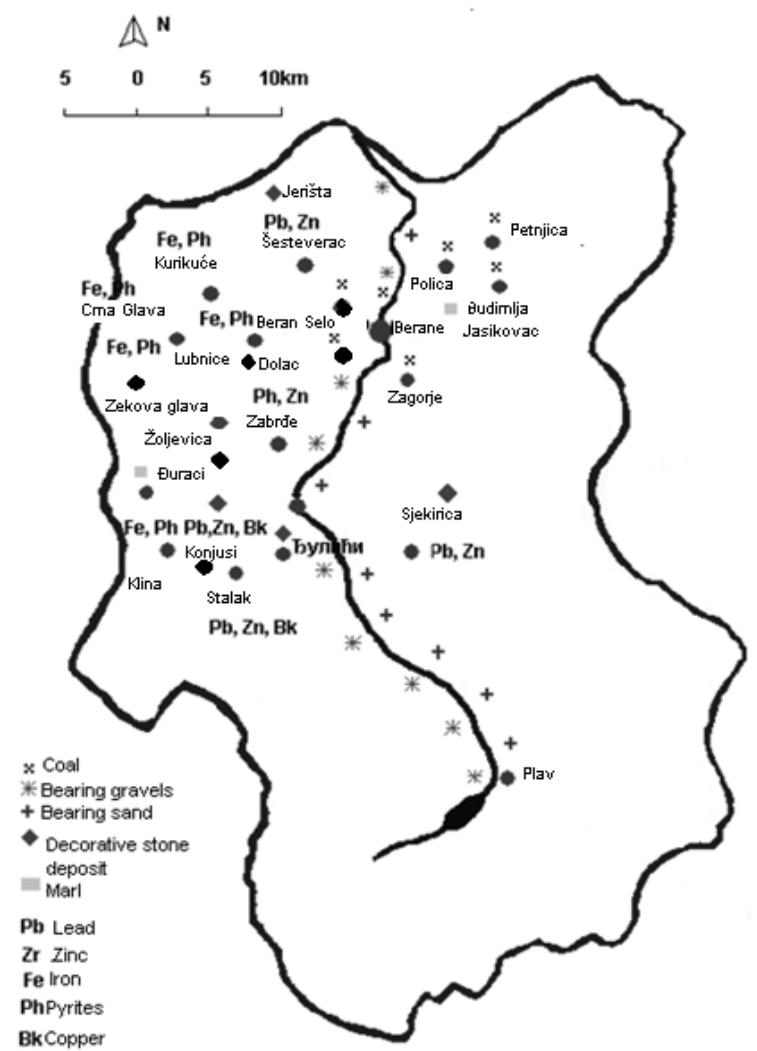

Figure 2. Mineral resource in Northeastern Montenegro

III Area - include the high mountain belt above $1.700 \mathrm{~m}$ as in this region exacerbated by the relief, thermal and land conditions. The slope of the spatial structure of the completely dominant slopes is over $18^{\circ}$, and slopes over $20^{\circ}$. Most land is represented as calkomenasol, litisoli, rendzina and podsol, so this area under forest vegetation and mountain pastures with blueberry and juniper (except where the parent material litisoli). Length of growing season with $\mathrm{Td} \geq 10^{\circ} \mathrm{C}$ is less than 90 days, the sum of active temperature $\mathrm{Td} \geq 10^{\circ} \mathrm{C}$ for $1.100^{\circ} \mathrm{C}$ and the mean daily temperature is less than $4.9^{\circ} \mathrm{C}$, a maximum height of snow is greater than $240 \mathrm{~cm}$ in the winter months. That is to say that this area suitable for tourism development, there are six lakes (Ridsko, Visitorsko, Pešića, Little Šiško, Big and Small Ursulovačko), which may be used for the development of sports and recreation, sports and various events, sports and hunting, excursion tourism. In addition, in this region there are numerous mountain pastures. (Do Kobila, Lisa, Štavna...). During the winter, but summer here comes a large number of climbers from various countries. They like the attractive character of this region and provide a basis for further development of sports, hiking and hunting tourism to develop eco-tourism. It is known to stay at this height suitable for athletes, healthy people, but many patients and normalize are situation by improving defense power of the organism. However, this area is most suitable for the development of sports, skiing, mountaineering and rock climbing (Rajović, 2006).

\subsection{Water Resources}

In northeastern Montenegro by hydropower are most important Lim River and its tributaries. This was the most affected rivers water pattern, morphology and geological structure of the terrain through which the flow. The morphology of the terrain (riverbed slope) in the catchment provides excellent opportunities for hydro-energy utilization. In 1956/57 Group of experts "The energy project" from Belgrade drafted a report "Study of accumulation Plav". It provides hydro-energy use of Basin Water Lake with three variants of the rise of water (elevation $945 \mathrm{~m}, 933 \mathrm{~m}$ and $917 \mathrm{~m}$ ) and with a dam Gradac hill, not far from the exit from Lima Lake. All three variants provide for fully immersion not only Plav Lake already and valley River Ljuča.The projected hydropower's "Plav" is a $24 \mathrm{MW}$, and would mean are first of 11 planned hydroelectric Lim (www.beranetown.net). According to data from the Regional Business Center Berane (www.nasme.me), which refers to "the study of energy use and its tributaries Lima" only in Plav, it is possible to build 15-hydropower formidable strength of $42.595 \mathrm{MW}$. Several power plants would have a very good performance in terms of power, potential, and the annual cost per $\mathrm{KW} / \mathrm{h}$. For example, hydropower "Jara" on Komarača River is most interesting because it has the following characteristics: an installed capacity of $6.8 \mathrm{MW}$, the installed flow $3,85 \mathrm{~m} 3 / \mathrm{s}$, waterfall The $220 \mathrm{~m}$, and annual output of energy 21, 57 GWh. The project envisages the construction time of one year, with the length of the inlet pipe was $4.1 \mathrm{~km}$, length $570 \mathrm{~m}$ steel pipe with a diameter of $0,8 \mathrm{mi}$ final prices $\mathrm{KW} / \mathrm{h}$. So hydro "Jara" according to the study mentioned above, constitute by far the cheapest hydroelectric power plant in the former Yugoslavia. In conclusion, in this part of northeastern Montenegro to the present day, there is not a power plant, even though there are more on Lim suitable place for their construction. "Assembly of Andrijevica 2012 adopted the" Decision on credit obligations of the municipality in the amount of 1.200.000.00 Euros "for the realization of the construction of mini-hydro power plant on the cities water "Krkori." Project involves the reconstruction of water intake (catchment); replace asbestos-concrete pipes with a length of $4 \mathrm{~km}$ and construction of plants for the production of electricity at the breaking chamber city water. Designed mini-hydro power up to $1 \mathrm{MW}$ are size of the facility $12 \mathrm{~h} 8 \mathrm{~m}$, height $5,5 \mathrm{~m}$. Private company from Andrijevica "Igma Grand" in 2012 received a concession for the construction of small hydropower installed capacity of 950 kilowatts, and the planned annual production of $3.383 \mathrm{GWh}$ on the river Bradavec for a period of 30 years and with the appropriate concession fee. In this way, with the production of electricity in the region, create the conditions for job creation. In addition to energy use, the accumulated water could be using for industry, water supply, irrigation of agricultural land.... The problem of water supply of population and industry are usually solving together. Water 
supply Berane Andrijevica and Plav in a modern way began in the early sixties. In doing so, they generally stronger capped karts springs. Water supply Berane devoted the greatest attention, because of population growth and industrial development. The construction of urban water supply in Berane began in 1962 and this regulation "the Monastery springs" whose capacity was 85 1/s. Today it serves as a backup source of water supply for the urban part of Berane. Since 1989, the water supply is part of the urban and suburban areas Berane in made from water Lubnice - Berane, which is supplied with water from the catchment "Merić" fountainhead. "Length of distribution network (primary and secondary) is $160 \mathrm{~km}$ long and covers about $70 \%$ of the municipal territory, and uses about $65 \%$ of Berane (www.nasme.me). Rural part of Berane Polica, Upper Budimlja, Dapsića, and Petnjik supplied with water from "Dapsićkog hot" with a capacity of $49 \mathrm{l} / \mathrm{s}$. According to data from the Municipal Secretariat for Economy Berane the Municipal Assembly are per capita water consumption in 1975 year $0,31 / 106 / \mathrm{m} 3,1985$ $1,21 / 106 / \mathrm{m} 3,19911,91 / 106 / \mathrm{m} 3$. If the calculated average in $\mathrm{m}^{3} /$ day then it ware 0,003 in 1975year 0,006 in 1985 and 0,01 in 1991. On the other hand, the water consumption in the industry ranged from $1,07 / 106 / \mathrm{m}^{3}$ in 1975 year $1,16 / 106 / \mathrm{m} 3$ in 1985 and $1,80 / 106 / \mathrm{m}^{3}$ in 1991 . In the mentioned period, total water use in Berane for population and industry, was $1,38 / 106 / \mathrm{m}^{3}$ u 1975 year, $2,37 / 106 / \mathrm{m}^{3}$ in 1985 and $3,75 / 106 / \mathrm{m}^{3}$ in 1991 . According to data from the Municipal Secretariat for Economy Berane Municipal Assembly in 2000, the total need for water Berane amounted to 5,62 million $\mathrm{m}^{3}$, of which the needs of the population 2,96 million $\mathrm{m}^{3}$ and 2.66 million $\mathrm{m}^{3}$ industry. Plav has a dense network, but not abundant karts springs and wells, which reduces the possibility of its permanent supply of drinking water. For now, supplied with water from springs and aquifers ("Đurički alluvion of the River"), with an average yield (15 l/s), less than the total needs. The Plav feels chronic water shortages in the summer period, particularly in rural locations Gusinje and Murino. Insufficient water supply of the population followed by many other rural towns: Prnjavor, Brezojevice, Kruševo, Martinoviće ... It is important to point out that the water pipes in the Plav obsolete and made of asbestos (main lines - profile of $200 \mathrm{~mm}$ and $110 \mathrm{~mm}$ ) and plastic - other lines. This circumstance causes huge losses in the network, which is estimating at more than half the amount of water transported in the pipeline. Length of the water is about 5, 2 $\mathrm{km}$, profiles 300 and $280 \mathrm{~mm}$, the primary distribution line is a distance of about $5 \mathrm{~km}$, and the total length of the secondary network is about $10 \mathrm{~km}$. In Gusinje is also plumbing, plastic pipes overall length of $6.5 \mathrm{~km}$. Primary local area network made of asbestos with a length of about $4 \mathrm{~km}$ and profiles 150 and $100 \mathrm{~mm}$, and a secondary plastic pipe length of about $6 \mathrm{~km}$. In Murino in identical supply pipeline built of plastic, with a total length of $5,5 \mathrm{~km}$ in length and a local network length is about $2 \mathrm{~km}$ and derived from plastic pipes (www.nasme.me). According to data from the Municipal Secretariat for Economy Municipal Assembly Plav, blue water consumption in 1991 was 3.05 million $\mathrm{m} 3$, of which the industry consumed 1.18 million $\mathrm{m} 3$, and the population of 1,87 million $\mathrm{m}^{3}$, i.e. $61,31 \%$ of the total. Total needs for Plav Water in 2000 amounted to 3, 97 million $\mathrm{m}^{3}$, of which the needs of are the population is $1 / 2$ of the overall needs, i.e. 1,99 million $\mathrm{m}^{3}$ and 1,98 million $\mathrm{m}^{3}$ and industry. The first water system for organized water supply in built in 1931 Andrijevica a capacity of $0,3 \mathrm{l} / \mathrm{s}$. At the end of the eighties, "Water of economic organization for the development and utilization of water of Montenegro" - Podgorica did a "major water project for Andrijevica", taking into account the then current situation and future social and economic development of urban settlements in the immediate environment which includes rural areas: Andželati, Božići, Bojovići, Đulići, Kralje, Prisoja, Seoce and Slatina. Water supply began 1982 are the arrangement of the springs "Krkori". Projected water system in built from cast-iron pipe diameter of $300 \mathrm{~mm}$ (www.nasme.me). After the road Andrijevica - Cecuni - Kuti in 1984, made amendments to the "Main Project" which is performed by the current water supply system, which relates to revise previously constructed road route over the pass "Pear". Finally, in the "Project of reconstruction of water supply system "source "Krkori" - Andrijevica is been designed, the second time, by making the correction of pipeline related in order to improve hydraulic conditions and that is part water supply system displace on her more accessible part it is along the road to by source "Krkori." So today, besides urban settlements Andrijevica from this water supply system supply and rural: Đuliće, Bojoviće, Seoce, Božiće, Prisoja, Slatina, Zabrđe and Trešnjevo (www.andrijevica.me). According to data from the Municipal Secretariat of Economy of the Municipality Andrijevica, total water consumption in 1991 amounted to 2, 06 million $\mathrm{m} 3$, of which the industry consumed 0,26 million $\mathrm{m} 3$, and the population of 1,8 million $\mathrm{m} 3$. Benefits for irrigation of farmland in the region are different. Flies are primarily available water, quality land types and morph metric predisposition. Therefore, the use of river water for irrigation in the northeastern part of Montenegro, in time and space is limited. The striking discrepancy between the amount of available river water and the required amount of water for irrigation is related to the July and august. So Plav at the station, Lim has a mean monthly flow of 13, 7 $\mathrm{m}^{3} / \mathrm{s}$ (July), 6, $8 \mathrm{~m}^{3} / \mathrm{s}$ (August), and the station Berane 20, 8 $\mathrm{m}^{3} / \mathrm{s}$ (July) and $11,4 \mathrm{~m}^{3} / \mathrm{s}$ (August). During the summer months (July, August, September), during the lapse of the river $9-12 \%$ of the annual flow, which is near Plav 17,8 $\mathrm{m}^{3} / \mathrm{s}$, and near Berane $37,4 \mathrm{~m}^{3} / \mathrm{s}$ (Rajović, 2009). In addition, many of the rivers in this period are below the biological minimum flow, and a deficit of irrigation water more pronounced. In relation to morph metric analysis relief benefits, the most favorable conditions for irrigation have alluvial Berane, Andrijevica and Polimlja valleys. Special benefit the construction of reservoirs on tributaries 
of Lima is contained in their hypsometric favorable position in relation to arable land at the bottom of Berane, Andrijevica and Polimlja Valley and Plav-Gusinje basin. Optimal opportunities to build reservoirs valleys provide aggressive and mosquitoes. Channel network of reservoirs in these flows could easily usher along Plav-Gusinje basin. For downstream basins should be considering in are formation of small reservoirs Zlorečica, Bistrica and Lješnica. Therefore, water management solutions in should be sought within the Spatial Plan of Montenegro, which refers to that part of, water management and water law, where it is necessary to set the focus on the construction of the regional water supply, irrigation and drainage (Rajović,2010). Accurately establishing the required amount of water for irrigation is not been performed. In the region of 29.787 ha of arable land is irrigating only about 1.000 ha. To irrigate small plots of vegetables and water to wells or water from are riverbeds. Most irrigated by surface is in Berane valley 550 ha. In the region, there are a small number of mineral springs but unexplored so neither valorized. Among them the attention it deserves, the thermal mineral springs in the village of kings. Taking into account classification (Leko et al, 1922) as well as minimum and gases in groundwater in establishment group mineral, thermal mineral springs in are village Kralje belongs to the sulfur waters. These are water in which the boundary between fresh and mineral water is around 0,001 and the minimum for inclusion in the thermal waters of 0,010 , which is very fitting parameters of this fracture sources. Certainly this and other thermo-mineral springs that requires special attention and work on their tourist valorization. Experience and research have shown that the thermal waters are suitable for the treatment and rehabilitation of cardiovascular diseases, respiratory diseases, diseases of billiard tract and pancreas in diseases of the gastrointestinal tract, metabolism, kidney and urinary tract, gynecological diseases, neuropsychiatric diseases, skin diseases, children's diseases. The combination of this with each other complementary (positive) tourism means progress in the evaluation of mineral water (Marković, 1979). It should be borne in mind that these resources can be using for other purposes, primarily in sports - and excursion manifestation.

\subsection{Deposits of Cool, Metal Ores and Non-Metal Ores}

Coal is an important natural resource in the region and provides a solid base for the development of the energy sector. The sediments of the upper Oligocene and lower Miocene in Berane and basin Polica there are deposits of lignite-brown coal. Berane basin is representing by gravel, sand, clay and marl. Developed three coal seams are the main coal, the first and second footwall. The main coal seam thickness ranges from 1-10 m, locally to separating, which means that the thickness inlays consisting of marls, ranging up to $1 \mathrm{~m}$. Tertiary main coal seam are carbonaceous and sandy clay. The thickness of are first coal seam varies from $1,2 \mathrm{~m}$ to $3,8 \mathrm{~m}$ and was developing in the district Petnjik - Dapsića. Tertiary other footwall carbon layer is gray and gray-green clay, and the thickness ranges from 2, $0 \mathrm{~m}$ to $4,5 \mathrm{~m}$. Thus, coal Berane coal basin type is lignite-brown coal (Nikolić and Dimitrijević, 1990). Basin Polica is representing by sandstones, sands, sandy clays, clays and marls, and it was concluding six coal seams. Their number and distribution in different parts of the basin is variable. The carbon layers are often separating, and their thickness ranges from $0,2 \mathrm{~m}$ to $7,2 \mathrm{~m}$. Coal Basin shelf also is among the lignite-brown coal. Based on petro graphic and chemical composition and macroscopic properties, coal Berane - basin Polica in largely built of detritus - Textile. The mean content of the petro graphic components of coal provides $86,6 \%$ detritus - Textile, detritus $3 \%-10,3 \%$ gel and textiles - the gel. From the data of technical analysis can been seeing that coal contains $16-20 \%$ moisture, $10-17 \%$ ash, and $2 \%$ sulfur, $45-50 \%$ of coke, about $30 \%$ fish-s, about $35 \%$ of volatile and over $52 \%$ of combustible substances. In addition, the effect of thermal coal amounts to $16.700 \mathrm{KJ}$ (GTE), and $13.400 \mathrm{KJ}$ (DTE) (Nikolić and Dimitrijević, 1990).

Total reserves of coal in Berane-basin are Polica 176.231 197 tons. It is widespread in all parts of Berane lowland (Budimlja, Petnjik, Zagorje, Polica, Beran Selo, and Dolac). Excavation of coal in this basin started in the sixties in the district "Budimlja" and was completing in the late seventies, when I started building a new mine investment district "Petnjik" that began production in 1981 in the eponymous pit, where and today is exploitation of coal. Production of coal ranged from 10.000 in 1960 to 107.000 tons in 1989. In the same period, coal production has increased from 276.000 to 2.159 million tons, or at a rate $8,25 \%$.Brown Coal Mine "Ivangrad" not escaped the fate of the collapse of the economic giants in our country. At the beginning of the nineties was sinking more and more in an uncertain economic future. In 2004 found to be insolvent. On the ninth bid for 1, 51 million Euros, the Greek company "Balkan energy" purchased the mine in 2008 and received its exploitation concession for 20 years. With the obligation to build a thermo-block of 110 megawatts over the next four years, invest another 120 million (www.mans.co.me). However, the extraction and processing of coal are still waiting, and mining for now is only considering a potential resource periodically. Program Development in Berane coal basin (lignite and brown coal $\approx 180$ million), would cause the intense regrouping and integration of industrial enterprises in this part of northeastern

Montenegro, which could cause are the need for capacity expansion (Beran Village, Dolac). Communication between them is relatively inexpensive and applicable to the road network, which mainly goes through the river Lim. The roads are second and third rows and are oriented in three directions and the direction north to Bijelo Polje, east to the south to in Rožaje and Andrijevica. Through these routes was connectivity with other parts of Montenegro, and Serbia. The nearest railway station on the Belgrade-Bar, located in Bijelo Polje, at a distance about $35 \mathrm{~km}$ from the 
mine. If we add to all this in Berane basins, there are immense reserves of marl. Marl especially is on the right side of Lima, mostly on the shelf, Jasikovac, but in the hamlet Đurake. These marls same qualities match the requirements of the cement industry. According Lutovac (1957) only on Jasikovac reserves could be providing for the production of two hundred years should be annually produced 80.000 tons of cement (Boričić et al, 1967). In the considered geographic space are detecting and the appearance and bearing the following metals: lead, zinc, copper, iron and pyrite. They occur in sedimentary and volcanic rocks: Paleozoic, Lower and Middle Triassic. Occurrence of lead and zinc were discovered east of Konjuhe on the right side of the river Perućica stand on the site. Demonstrate an area of about $2 \mathrm{~km}$. They occur in the Permian sediments, Lower and Middle Triassic. Mineralization occurs in the form of wires and impregnation, and their thickness ranges from $0,2 \mathrm{~m}$ to 1,0 $\mathrm{m}$. The content of zinc in the wires is very variable, in some trials reaches $5 \%$, while the middle is $0,3 \%$, while the content of lead is far smaller and does not exceed $0,1 \%$. Besides lead and zinc in Konjusi occurs and copper, whose average content is about $0,15 \%$. Association Konjusi minerals are: pyrite, sphalerite, chalcopyrite, galena and others. The mineralization is genetically related to diorite and quartz diorite, and was created at higher temperatures and lower levels (Group of authors, 1982). On the right side of the river, Lima in the area between the axes Kostreš, Omarska, and head were discovered also the appearance of lead and zinc. They occur in quartz-keratophyre, tuffs, volcanic breccias and limestones. Mineralization is manifesting in the form of wires. The content of lead and zinc ore FACING pieces ranging up to $6 \%$ of lead and zinc. In this area of land in some trials of zinc content ranges up to $1,1 \%$, and lead to $0,8 \%$. Mineral association of the hatchet is pyrite, sphalerite, galena and chalcopyrite. On the eastern slopes of the wider area of Bjelasica in Zabrđe and Šestaverca and wire thickness, not exceeding $1 \mathrm{~m}$ and the provision is rarely following for longer than $20 \mathrm{~m}$. The content of zinc in the ore wired King's Brook is 2, $5 \%$ or $3 \%$, in Border Creek to $0,5 \%$ in Vaćevinama to 0 , and $2 \%$. Occurrence of copper in found in the creek beside Konjuh stand. They occur with lead-zinc mineralization. Copper content of this locality ranges from $0,1 \%$ to $0,2 \%$ levels (Group of authors, 1982). Occurrence of iron was discovering in the mountains Bjelasica in a number of localities: Kurikuće, Lubnice, Zekova Glava, Crna Glava, Strmi Pad, Konjusi (site of Klina). Occurrence of iron in Bjelasica occurs in the form of hematite, which is to say that the hematite occurs along the plate with red charts, which lie over keratophyre and below the slope of layered limestone. Iron content in these localities ranges from 17\% - 33\%. In the Clinical Konjuh iron ore presented hematite, and manifests as a contact lens on the volcanic rocks and limestone. Occurrence of pyrite have found in a number of localities on the mountain Bjelasica: Zekova Glava, Kurikuće, Lubnica, Crni Vrh. Pyrite occurs in the form of wires in the form of impregnation, as well as volcanicsedimentary rock formation. Wire pyrite in the Paleozoic sediments ranges from 0,1 to $1 \mathrm{~m}$ (www.andrijevica.me). From nonmetallic mineral resources on the observed geographic, there are deposits of building materials: gravel, sand and decorative stones. Numerous deposits of gravel and sand in found in the bed of the river Lima (Plav, Andrijevica, and Berane). Only in Bandović Most, the amount of gravel and sand, available for an annual extraction is estimating at approximately $100-120.000 \mathrm{~m}^{3}$. In the northeastern part of Montenegro there are limestone quarries in the Triassic. There is a certain amount of building stone, which can be exploiting locally, but the conditions are unfavorable for continuing exploitation. When it comes to the exploitation and processing of marble and ornamental stone, it should be noted that there are multiple sites of different architectural building stone and marble, the most significant: the site Trebačka River, Seoce, Piševska River, Babov Stream, Pčelinjak, Žoljevica. Outcrops of volcanic rocks in the upper reaches of the river Trebačka appear on the left and right, from an altitude of about $850 \mathrm{~m}$, while only the riverbed is covering with blocks of the same rocks. For natural cane, the rock is pale green, and the fresh green and gray-green layout. On the surface are also observed cracks some of which are open and wide and ten centimeters fall allow larger blocks rocks. In the cutting path that leads from the hamlet Gunjaje, Steppe to summer pasture at an altitude of $1.170 \mathrm{~m}$ to 1.185 , were discovered brecciate limestone's. According to the geologic map of Montenegro 1:10.000, these rocks are represented and northwest of the hamlet Gunjaje. At about twenty meters in a south east direction, there is a slit in which the traces of mine holes, which means that the stone used probably as a quarry for the construction of residential buildings (www.andrijevica.me). Outlet Piševo rocks in the river are an integral part of the volcanogenic massive axes, which covers an area about $25 \mathrm{~km}^{2}$. From rock to been discharged and are represented by andesitic keratophyre, volcanic breccias and tuffs, with mutual crossings. The presence of andesitic is most pronouncing on the western slopes Piševa and in the middle and lower reaches of the river Piševske. These rocks are particularly revealing in the notches of the forest road that goes along with Piševsku River with her right hand. The rocks are gray-green to bluegreen color. Scorn resulting changes of carbonate rocks, mainly Lower Triassic bio-turbine formation, build terrain in high stream flows Bradevec, Babov and Malinovac. The rocks are best discovering in the bed of the stream Babov, which occur at an altitude of $1.170 \mathrm{~m}$ to $1.600 \mathrm{~m}$. Scorn, are very compact and sail rock, usually striped texture. Their color is mostly gray and grayish-green, are being observing and one yellow-green and jonquil, which of course depends on the mineral composition. Brecciate limestone and dolomite limestone were discovered on the ridge of the bee, at an altitude of $1.150 \mathrm{~m}$ to $1.450 \mathrm{~m}$, followed by delivery to the west, southwest and nameless streams, gullies actually. At the ridge, the terrain is covered 
and covered, so that the boundary between the reddish limestone and gray crystalline limestone, which are below them, masked and unclear (www.andrijevica.me). Žoljevica on the hill is the cradle of architectural - building stone. This deposit build medium - gray and white Triassic massive limestone mesmerist. Mesmerist white limestone on the surface, covering an area of about $3.000 \mathrm{~m}^{2}$, and its thickness is about $30 \mathrm{~m}$, while mesmerist gray limestone, covers an area of $30.000 \mathrm{~m}^{2}$ and has a thickness of about 50 $\mathrm{m}$. Resource estimates of gray marble $\mathrm{B}+\mathrm{C} 1$ category, amount to 2.223 million $\mathrm{m}^{3}$. Reserves gray-white marble and white marble belong to the $\mathrm{C} 1$ category and amount to about $60.000 \mathrm{~m}^{3}$. Decorative stones of this deposit is very decorative, perfectly polished, and attains a high sheen. Due to their physical - mechanical properties of rock, 'Žoljevice" can be used to produce plates for covering horizontal and vertical surfaces, objects in the construction industry (www.andrijevica.me).Geological studies performed during the 1955 and 1963, defined the following characteristics of stone: the size and shape of the bearing, physical and mechanical properties of white and gray varieties, so that the cutting test, the white variety have broken down completely, while the gray variety, obtained plates of excellent quality and a beautiful shine. Based on the above data it can in say that the bay "Žoljevica" fully defined in terms of quantity and quality. However, it is not marble survey received sufficient attention, despite the fact that the site be considered after the Arandjelovac and Prilep, can be considered as one of the most significant in the former Yugoslavia (Lutovac, 1973).

Wonderful marble with "Žoljevice" we should "valorize" the art-tourism event, "Marble and Sounds." Far lead us to emphasize, what are the riches and what possibilities the marbles and marble breccias, provided the northeastern part of Montenegro, for its economic development. There are various estimates of mineral reserves in the northeastern part of Montenegro. However, research that is smaller or greater intensity exercise, lead to the discovery of new ore deposits, and are not prone to such estimates. However, we believe that mining in limited geographic space, given the presence of mineral resources, i.e. their diversity and reserves, only part used the opportunities that it provides the raw material base ( Rajović and Bulatović, 2013 a).

\subsection{Agricultural Areas and Forests}

Agricultural land is an important part of the natural wealth of the region. The structure of land use in certain categories is of special importance because it is the result of development and intensity of agriculture and it expresses the degree depending territorial conditions for the development of certain types of agricultural production (Todorović, 1985). In the period 1964-2005 in the agricultural land of the region there has been a change in the manner of utilization to reduce the area under fields and gardens and pastures (Table 1). In contrast increased area the under orchards and meadows. Arable land in the reporting period was reducing from 8.440 ha in 1964 to
7.368 ha in 2005 up to 1.072 ha. Area under orchards increased in are same period from 1.826 ha to 2.334 ha or 508 ha. During the reporting period of are meadows slightly increased from 19.926 ha to 20.502 ha or 576 ha. Land pastures in the period 1964 - 2005 decreased from 40.286 ha to 37.821 ha or 2.465 ha (Table 2). Given the state of mind of the livestock and the degree of degradation of pastures, it is logical to expect a further decline in this category of land. Point out only the following information, which fully reflects the condition of livestock in the region. In the period of 1994-2005 the total number of cattle has decreased from 41.506 to 27.593 head or 13.913 throat, pigs from 4.264 to 2.480 or 1.784 head cattle, poultry from 92.261 to 58.770 a piece, or a piece for 33.491 . Only the sheep remained almost same. In 1994 the region has grown 68.534 sheep and 68.660 in 2005. On livestock development tendencies in the region was affecting by several factors: the extensive character, throat low productivity management retarded way.... (Rajović, 2012).

Table 1. Agricultural area by categories use in northeastern Montenegro 1964 and 2005

\begin{tabular}{lcccc}
\hline \multicolumn{1}{c}{ Year } & \multicolumn{2}{c}{1964} & \multicolumn{2}{c}{$\mathbf{2 0 0 5}$} \\
\hline $\begin{array}{l}\text { Category land } \\
\text { Agricultural }\end{array}$ & $\mathrm{u}$ ha & $\%$ & $\mathrm{u}$ ha & $\%$ \\
$\begin{array}{l}\text { areas } \\
\text { Fields and }\end{array}$ & 70.478 & 100 & 67.379 & 100 \\
gardens & 8.440 & 11,98 & 6.722 & 9,98 \\
Orchards & 1.826 & 2,59 & 2.334 & 3,46 \\
Meadows & 19.926 & 28,27 & 20.502 & 30,43 \\
Grasslands & 40.286 & 57,16 & 37.821 & 56,13 \\
\hline
\end{tabular}

Source: Statistical Office of Montenegro, Census of Agriculture (the relevant year), the calculation of data by the author

Table 2. Sowing structure arable area northeastern of Montenegro in 1964 and 2005

\begin{tabular}{lcccc}
\hline \multicolumn{1}{c}{ Year } & \multicolumn{2}{c}{1964} & \multicolumn{2}{c}{$\mathbf{2 0 0 5}$} \\
\hline Category land & $\mathrm{u}$ ha & $\%$ & $\mathrm{u}$ ha & $\%$ \\
Fields and & 8.840 & 100 & 6.722 & 100 \\
gardens & 6.350 & 75,24 & 1.127 & 16,77 \\
Grains & 26 & 0,31 & - & - \\
Industrial Crops & 1.305 & 15,46 & 2.680 & 39,87 \\
Vegetables & 759 & 8,89 & 2.036 & 30,29 \\
Fodder crops & - & - & 879 & 13,08 \\
Uncultivated & & & & \\
arable land & & &
\end{tabular}

Source: Statistical Office of Montenegro, Census of Agriculture (the relevant year), the calculation of data by the author

According to the data from Table 1 in agricultural land in 2005 there was the arable land 9,98\%, 3,46\% orchards, meadows and pastures 30,43\% 56,13\% (Table 3). Such a large percentage of meadows and pastures in are overall structure of agricultural land, indicating the mountainous character of the region. Arable land is the most important category land. However, statistics show that spontaneously abandoned arable land or planning translated into other categories of land, or alienating for non-agricultural 
purposes. Threaded with a reduction in the area under arable land, there comes a change in the structure of its use. The use of the structure of the arable land in the period 1964-2005, noted the positive changes in the direction of increasing the area under vegetable crops (1.305 ha- 2.680 ha), cattle fodder (759 ha -2.036 ha). Adverse changes in the structure of use are contained in the fact that the area under cereals decreased (6.350 ha- 1.127ha), abolished under industrial plants (26 ha - 0), and increase the area under fallow land (for the 879 ha). The increase has been causing by the phenomenon of elderly households that are not able to cultivate their property. However, the raw surfaces are result of negligence of state and local governments by the surplus of agricultural products. According to the data from Table 2 in the structure of the arable area in 2005 , there was the corn $16,72 \%, 39,87 \%$ Vegetables, animal fodder $30,29 \%$ and $13,8 \%$ uncultivated arable land. Thus, the formation of such a structure using arable land, in addition to natural conditions, demographic trends are affected, the inability to use modern agricultural mechanization, irrigation, tradition ...( Rajović and Bulatović, 2013 c)

Table 3. Utilization of agricultural land in northeastern Montenegro 2005

\begin{tabular}{|c|c|c|c|c|}
\hline \multirow[b]{2}{*}{$\begin{array}{c}\text { Categories of } \\
\text { land and } \\
\text { culture }\end{array}$} & \multirow[b]{2}{*}{ ha } & \multicolumn{3}{|c|}{$\%$} \\
\hline & & $\begin{array}{l}\text { Participation } \\
\text { in group }\end{array}$ & $\begin{array}{c}\text { Fields } \\
\text { and } \\
\text { gardens }\end{array}$ & $\begin{array}{l}\text { Farmer } \\
\text { surface }\end{array}$ \\
\hline $\begin{array}{l}\text { I. Fields and } \\
\text { gardens }\end{array}$ & 6.722 & & 100 & 9,97 \\
\hline A. Grains & 1.127 & 100 & 16,76 & 1,67 \\
\hline Corn & 930 & 82,52 & 13,84 & 1,38 \\
\hline Wheat & 153 & 13,58 & 2,28 & 0,22 \\
\hline Rye & 17 & 1,51 & 0,25 & 0,02 \\
\hline Barley & 27 & 2,39 & 0,40 & 0,04 \\
\hline B. Vegetables & 2.680 & 100 & 39,87 & 3,97 \\
\hline Potato & 2.010 & 75,0 & 29,90 & 2,98 \\
\hline Beans & 138 & 5,15 & 2,05 & 0,20 \\
\hline $\begin{array}{l}\text { Other } \\
\text { vegetables }\end{array}$ & 532 & 19,85 & 7,91 & 0,78 \\
\hline $\begin{array}{l}\text { C. Fodder } \\
\text { crops }\end{array}$ & 2.036 & 100 & 30,29 & 3,02 \\
\hline Alfalfa & 319 & 15,67 & 4,75 & 0,47 \\
\hline $\begin{array}{l}\text { Other cattle } \\
\text { fodder }\end{array}$ & 1.712 & 84,33 & 25,54 & 2,54 \\
\hline D. Fallow land & 879 & 100 & 13,08 & 1,30 \\
\hline II. Orchards & 2.334 & 100 & & 3,46 \\
\hline III. Meadows & 20.502 & 100 & & 30,42 \\
\hline IV. Grasslands & 37.821 & 100 & & 56,13 \\
\hline TOTAL & 67.379 & & & 100 \\
\hline
\end{tabular}

Source: Statistical Office of Montenegro, Census of Agriculture (the relevant year), the calculation of data by the author

Arable land is mostly using for sowing harvest. In area, where corn was grown in are region's dominant cereal (930 hectares or $82,52 \%$ ). However, the total area under maize fields and gardens accounts for 13,84\% and 1, 38\% of the total agricultural area. Thus, areas sown with maize are small and primarily determined by the amount of rainfall during the growing season, especially the government deficit in July and August, when the corn is in the process of maturing grain. Stable yields of maize in the region can be ensuring irrigation of arable land. However, if one takes into account the temporal and spatial distribution of water suitable for irrigation is insufficient, and that they mainly used for irrigation of vegetable crops, then small amounts of water remain so available for irrigation area under maize. Wheat is the most abundant plant other crops in the region (153 ha or $13,58 \%$ ). The total area under wheat fields and gardens accounts for $2,28 \%$ and $0,22 \%$ in total agricultural area. Despite cultivars of use and considerably modern agricultural practices in the basin Berane, wheat yields significantly determined by the agro-climatic conditions. However, the cultivation of wheat in the region decreases significantly due to the high cost of its production and labor shortages, and because of the simple reason that it is cheaper to buy bread in the shops than "look at the wheat field and worry about what will be her next race and the effort and costs"(Jaćimović, 1971). The grain structure similar changes have occurred in the rye and barley. Thus rye harvested areas in the region amounted to 17 ha, or $1,51 \%$, barley 27 ha or $2,39 \%$ of the total area under cereals. The total area under rye fields and gardens accounts for $0,25 \%$ and $0,40 \%$ barley or rye with barley and $0,02 \%$ at $0,04 \%$ of the total agricultural area. Both cultures tolerate cold, drought, and even moisture, and succeed where other cultures would be difficult to adapt. In addition, are the area under these crops has reduced, as are grown for their own use and in small areas and less fertile soils. Greatest importance in are diet of the region, in spite of changes in the way of growing a fodder with natural grasslands and arable land under livestock fodder. Moreover as are, fodder for feeding cattle, sheep and much less use and cornstalks (Rajović and Bulatović, 2013 d).

In 2005 the area of fodder production was 2.036 ha or 30 , $29 \%$ of the total arable or 3,02\% of the total agricultural area. Sown area of 1 alfalfa amounted 319 ha or $15,67 \%$ of total area under livestock fodder or $4,75 \%$ compared to arable or $0,47 \%$ of total agricultural land. In the same period, the area under other livestock forage crops (clover, vetch, a mixture of grasses) encompassed an area of 1.717 ha or $84,33 \%$ of total area under forage crops or livestock $25,55 \%$ compared to arable or however, 2, 54\% of total agricultural land. The main reason for under-sown areas under cattle fodder is due to poor implementation, technology inappropriate select varieties and safeguards. Areas under natural grasslands amount 58.323 ha. The surface of 20.502 ha of meadows and pastures 37.821 ha share in total agricultural area with $30,42 \%$ and $56,13 \%$. Dying of sheep and goat farming in this region, more meadows and pastures win a variety of shrubs and weed communities. Weed vegetation occurs in a large number of species in agricultural areas, along roads and boundaries. The representatives are Nettle (Urtica dioica), dandelion (Taharacum officinale), spurge (Euphorbia cuparissias), wild oat (Avena tatua), thistle (Cirsium arvense), Buttercup 
(Ranunculus pepens), Burdock (Lappa majok), black mallow (Malva silvestris) and others. A combination of mechanical, chemical and biological methods can be suppressed weeds only during a rotation crop rotation, however, but in the next, he reappeared. Vegetable farming is one of the most intensive field crop production, due to the effort and the realized production. Total area under vegetable crops in 2005 amounted to 2.680 ha or $39,87 \%$ of the total arable land, and 3,97\% of agricultural land. Potato is the official statistics dominant vegetable crop. Under these vegetable crops there were 2.010 ha or $75,0 \%$ compared to the total sown area under vegetable crops, or $29,90 \%$ of total arable or $2,98 \%$ of agricultural land. The basic problem is even larger sown area under potato is the fact that despite the use of quality planting materials (the Dutch seed potato and homemade potato), the unfavorable rainfall patterns in the second half of the growing season. Beans grow best in fertile soil and loose, particularly at the upper flood plains of the region. Traditionally sown as intercrop maize, but the penetration of sunlight hinders its development. It has caused the so-called bean planting "Pure culture". The total area under bean in 2005 amounted to $138 \mathrm{ha}$, or $5,5 \%$ of the total area under vegetable crops, or $2,05 \%$ of the total arable land, or $0,20 \%$ of the total agricultural area. Other vegetables (onion, cabbage, cucumbers, pumpkins, peas ....) are very widespread in the region. Area planted to these kinds of vegetables amounts to 532 ha or $19,85 \%$ of the total area under vegetable crops, or $7,91 \%$ of the total arable land, or $0,8 \%$ of the total agricultural area. The introduction of new varieties, improved agricultural technology and organization of production, planted area under "other vegetables" may increase because there are natural - environmental conditions (Rajović, 2013).

Forests in northeastern Montenegro, according to the census of 1979 the forest reserves 63.718 ha are occupied, which means that $42,87 \%$ of the territory of the region is covered with forest vegetation (Table 4). According to statistics from 2005 the forest area as compared to 1979, decreased to 128.629 ha (area under forest cover 62.432 ha, and the forest coverage of $42,02 \%$ ). Reduced forest area, are not the result of a planning ways of management, lack of timely measures to protect against erosion, fire. Natural conditions in the region caused the structure of forest communities. The alluvial plains and terraces fluvial glacial Lima are characterizing by extremely low vegetation. Forests are mostly mixing, while the most common types are hydrophilic woods willow, poplar, alder, elm, oak, oak, beech, birch, maple. The belt of beech is most common in the form of your images: four: beech (at lower elevations), mountain beech forest at altitude $1.000-1.300 \mathrm{~m}$ above sea level, sub-alpine beech forest at altitudes greater than $1.800 \mathrm{~m}$ with spruce-dominated forests. With some of our mountainous stretch of the mountain forests moonlike and pine. Above this band represented the expanse of white and red pine. Some forest stands and makes the dwarf pine; whose propagation exceeds $2.000 \mathrm{~m}$ above sea level, or junipers, stops above $2.200 \mathrm{~m}$ (Rajović, 2007 b).

Table 4. Surface and structure of forest reserves in 1979

\begin{tabular}{|c|c|c|c|c|c|c|}
\hline Forest stand & Area in ha & $\%$ & Timber in $\mathbf{m}^{3}$ & $\%$ & Annual increment in $\mathbf{m}^{3}$ & Annual growth in $\mathrm{m}^{3} / \mathrm{ha}$ \\
\hline Decorated & 54.643 & 85,76 & 11.515 .192 & 82,95 & 208.721 & 1,81 \\
\hline Disorganized & 9.075 & 14,24 & 2.367 .324 & 17,05 & 31.193 & 1,31 \\
\hline TOTAL & 63.718 & 100 & 13.882 .516 & 100 & 239.914 & 3,12 \\
\hline
\end{tabular}

Source: Statistical Office of Montenegro List of growing stock in 1979, Edition "Studies and Analyses," Titograd, 1983.

Table 5. Forest structure in 2005

\begin{tabular}{lcc}
\hline \multicolumn{1}{c}{ Surfaces } & ha & \% \\
\hline High economic forests & 27.196 .24 & 43,56 \\
Low economic forests & 2.657 .17 & 4,26 \\
Protective forests & 17.972 .64 & 28,80 \\
Fallow land & 7.742 .19 & 12,40 \\
Bushes and shrubs & 6.858 .05 & 10,98 \\
TOTAL & 62.432 .29 & 100 \\
\hline
\end{tabular}

Source: Statistical Office of Montenegro, Census 2005, forest reserves, calculation of data by the author

Regarding the breeding categories, arranged dominated (high, low and safety) of forest. Specifically, of the total forest area in the northeastern part of Montenegro, the beautiful trees waste $85,76 \%$ (54.643 ha), and the disordered 14, 4\% (9.075 ha). The total density, estimated at $13.882 .516 \mathrm{~m} 3$, i.e. $82,92 \%$ (Table 5). In well is $11.515 .192 \mathrm{~m}^{3}$ or $82,95 \%$ of the total wood mass and disordered $2.367 .324 \mathrm{~m}^{3}$ (17, $05 \%$ of total wood pulp).
Annual volume increment amounts to $239.914 \mathrm{~m} 3$. At the same time, the increment tended forests $208.721 \mathrm{~m}^{3}$, while the disordered is $31.193 \mathrm{~m}^{3}$. The average value of annual increments were relatively small, amounting to $3,12 \mathrm{~m}^{3} / \mathrm{ha}$, beautiful trees $-1,81 \mathrm{~m}^{3} /$ ha, unregulated $-1.3 \mathrm{~m}^{3} / \mathrm{ha}$.

The structure of forests are most widespread economic forests that cover 27.196.24 hectares or $43,56 \%$, low economic forests 2.657 .17 ha or $4,26 \%$, protective 17.972 .64 ha or $28,80 \%, 7.742 .19$ ha of uncultivated land or $12,40 \%$ and scrub and bush 6.858 .05 ha or $10,98 \%$. According to statistics from the forest reserves in 2.000 shows a gross weight of timber felled was $76.873 \mathrm{~m}^{3}$, of which the trees is accounted for $25.122 \mathrm{~m}^{3}$ and $51.751 \mathrm{~m}^{3}$ of coniferous trees. Of the total cuts to technical wood accounted for $53.474 \mathrm{~m}^{3}, 13.525 \mathrm{~m}^{3}$ of firewood and scrap $9.824 \mathrm{~m}^{3}$. The annual increment of forests estimated $190.934 \mathrm{~m}^{3}$. So the volume of harvest is less than the increment of mass. To forest vegetation played a proper function for economic development in the region, it is necessary in the future to pay special attention to the 
preservation and reproduction of forest reserves, especially of high economic and protective forests. This implies the use of rational, reconstruction of devastated forests and extensive forestation, especially places that have been exposing to erosive processes. Careful cutting plan, taking into account are environmental and economic criteria. Wood processing industry in this part of northeastern Montenegro, we must pay special attention. Specifically, based on the use of forest resources, this industry is, so far, its development directed to finalize the primary production (timber, wood panels...). Direction main wood processing, must be defined production function, i.e. ensuring all products from the forest, which can be valorizing through wood volume production and other forest products. In addition, as the main forest product occurs virgin wood, either in the unprocessed (sawmill logs, firewood, lumber) or processed form (furniture, cellulose). The other products are some of the woods, which are gaining increasing importance: venison, fish, snails, berries and seeds, mushrooms, resins, essential oils, juices, roots, leaves, lichens, moss peat, stone, gravel, sand and ..., for which there is no prohibition on the collection. Before a hundred years or more livestock has largely rested on the use of forest products as an energy food, especially oak, beech acorns and wild fruit and chestnut. Today this method of feeding livestock remained largely a memory. From the economic point of flora forest (62.432 ha) and pastures (37.821 ha) is enriched with various kinds of medicinal plants and edible mushrooms. Especially important are certain types of mushrooms, wild strawberries, raspberries, cornelian cherries, rose hip, blueberries, juniper berries. In the region there are about 60 medicinal plant species. Most of them ranked highly in traditional medicine, pharmaceutical production, which is very important for are the tourism development. Medicinal herbs rich in its diversity, physiological and pharmacological effect, and a healthy quantity of raw materials, offers immense possibilities in the development health and educational tourism. From early spring until autumn at are latest, in the forests, meadows (20.502 ha), are growth of many types plants, most of which are edible and medicinal. Many of them with are highest nutritional values: Klamath weed, thyme... Wormwood used as a tea. Thanks to the widespread forests, pastures and meadows landscapes of the region are diverse and picturesque, providing significant environmental and tourism values and northeastern Montenegro seems very attractive. Meadows and pastures are covering with juicy mountain meadow grass and flowers, so that together with forests, a special landscape-decorative value region. Belt noise is particularly interesting as a living space of venison, birds, fish and insects that. Is the pearl of the unique natural beauty and tourist aspects unimpaired nature? With has significant resources and a predisposition to the development of different forms of tourism, such as fishing, hunting, adventure, puts the adrenaline. The first place is taken by hunting and fishing. In this regard, the region has a very pure nature and abundance of flora and fauna. The forests are rich in tiny and big game from that aspect is very interesting tourist destination for hunting tourism. Travel offers could include individual and group package tour for hunting small and big game: bear, deer, mountain goats, wild pigs, wolves, fox, rabbit, squirrel, grouse, partridge, wild duck, marten, badger, and others. Rivers and lakes are rich in fish (trout, grayling, brown cataracts, minnow, bullhead, and northern pike). For improving fish stocks, in particular salmonid stocks continued to implement stocking. By artificial stocking, one of the measures for improvement of fish stocks and is the determination of brood fish for the salmonid fish species. The most important brood fish were on the River Lim, Plav Lake and River Ljuča. Sport fishing deals with around 800 registered sport fishing and recreation. The large number of people in the region who regularly resides in nature should be with proper training, use it as an important and indispensable factor of its conservation. With sports - fishing, as well as the hunting, we should build primarily rural - tourism offer in the form of accommodation, local specialties kitchens and the like, service with a night in a hotel or hunting and forestry buildings.

\section{Conclusion}

Diversity and complementarily of natural resources is the main characteristic of the considered region, which is of special importance to its future economic development. Of course, no matter how natural resources in this part of northeastern Montenegro were great, they are not unlimited and inexhaustible. Therefore, their use must be planned and rational. Harmonious economic development in the future will depend on many factors, which are at the end of the twentieth century proved to be limiting. State of the economy at the beginning of the first century twenty is fraught with numerous problems. The concept of transition based on liberalization and privatization, has not brought the expected results. The slow and poorly conducted privatization processes that have caused the economic development Berane found at the very bottom in Montenegro, although once on this ground occupied third place, after Podgorica and Nikšić. The downfall of Berane industry started in the late eighties, when it came to closing the "pulp and paper" later "Beranka" and "New Beranka", which was the biggest economic giant in the region. Stopped is production in 1989. The factory was privatized in 2004, has since been repeatedly moved to production, but it all ended up on trying. Industrial zone "Rudeš" is a collection of dozens of abandoned factory halls, some of which been turned into scrap metal. There is no production in the coalmine "Ivangrad" as in IMG "Bricks". Neither are former leather factory drive "Polimka" not long ago published widely famous leather goods. Among settled collectives and found the factory for retreading "Gumig". Several agricultural cooperatives in Berane, no longer exist. The entire property JSC "Building" The door is in 
bankruptcy HTC Berane for many years, no one opens. And "Obod" drive on Rudeš has long been out of order. The only bright spot is the factory "Polieks" with the police who are engaged in the production of explosives and initiators. Besides "Polieks" and several small private companies in Berane are still working. Among them is the "Asphalt base" in Lower Ržanica, "shirt factory" Petnjica and "FIC - Polimlje" a company engaged in wood processing (www.beranetown.net). In Plav municipality companies that are backbone of development, have experienced a failed privatization or are in bankruptcy: "FIC - Bor", "A-SC - Alpet", "A-SC -Plav," agricultural cooperatives "Murina" Confection "Maxim" and the Murina in "Termoplast " from Gusinja "Metals Processing". The sale of part of the assets of the Agricultural Cooperative "Plav" for the recovery of claims of creditors and employees (www.gusinje-foundation.org). A similar phenomenon we see in the municipality Andrijevica. Unsuccessful privatization or bankruptcy characterized once very successful business collectives, "Soko Štark", "Termovent" list, leather factory "Polimka", "Stationery", Agricultural Cooperatives "Vasojevka" agricultural cooperatives "Andrijevica" agricultural cooperatives "Konjuhe". Shut down the company and "Marble". This state of the economy has caused high unemployment that has caused major socio-economic problems in the region. Intensification of socio-economic problems was emphasizing by "ill-treatment" of agriculture. "Given the current state of the economy ... balance and the current model, based on the sale of the company and copious outflow of capital, and its spillover into consumption, escalation global economic crisis has irreversibly exhausted (Bulatović and Rajović, 2007). At this point, we affirm clearly formulated position Grčić (1991), which indicates that the development problems and irrational economic system kept all the technical and scientific narratives, without being able to you any concrete action to implement. Then, and seems now, we were not able to rise above statement. Hence, the conclusion that it is necessary to develop a special economic strategy for innovative regional policy adapted to the hilly - mountainous regions, such as the right and discussed. Forecasting the future development of the region is difficult. Therefore, the conclusion that requires immediate access to defining regional development strategy to build economic competitiveness. By Cvijanović (2004): “There is a widespread perception that the organization is a valuable resource, as important as raw materials, energy, equipment, technology and personnel, and perhaps more important because it brings together all the resources and makes them meaningful .... In practical dealing with organizational issues, still dominate the descriptive and analytical approach, and lacks an active attitude towards the perceived organizational changes. The effectiveness and efficiency of the approach to solving organizational problems ... is diminishing due to the different individual conceptions and approaches". Of course, we are advocating for programs that meet high scientific criteria, and the willingness to appropriate institutions in the economic development of the considered space invests the necessary funds.

\section{References}

[1] Pavlović M, Šabić D, Vujadinović S. Natural resources as a factor of socio-economic development Polimlja, Journal Serbian Geographical Society, 2, 2009, 3-15.

[2] Gylfason T. Natural resources, education, and economic development, European Economic Review, 45(4-6), 2001, $847-859$.

[3] Rajović G. Mini projects in teaching geography, Pedagogical reality, 53 (3-4), 2007a, 205-213.

[4] Barbier EB. Natural resources and economic development, Cambridge University Press, 2007.

[5] Arezki R, Ploeg F. Do Natural Resources Depress Income Per Capita? Review of Development Economics, 15( 3), 2001, 504-521.

[6] Ploeg F. Natural Resources: Curse or Blessing? Journal of Economic Literature, 49 (2), 2001, 366-420(55).

[7] Albrecht D. Amenities, Natural Resources, Economic Restructuring, and Socioeconomic Outcomes in Nonmetropolitan America, Journal Community Development Society, 35(2), 2004, .36-52.

[8] Hopwood B, Mellor M, Brien O'G. Sustainable development: mapping different approaches, Journal Sustainable Development, 13 (1), 2005, 38-52.

[9] Rajović G. Natural conditions for the development of agriculture in northeastern Montenegro, Journal Industry, 37 (4), 2009, 15-27.

[10] Rajović G. Natural conditions for the development and deployment of tourism in northeastern Montenegro, Journal Industry, 38 (4), 2010, 182-203.

[11] Rajović G, Bulatović J. Some economic-geographic factors development of the example rural areas northeastern Montenegro, Russian Journal of Agricultural and SocioEconomic Sciences, 9 (9), 2012 a, 3-20.

[12] Rajović G, Bulatović J. Some geographical factors economic development of rural areas in the manicipality of example Andrijevica (Montenegro), Russian Journal of Agricultural and Socio- Economic Sciences, 5 (5), 2012 b, 3-16.

[13] Rajović G, Bulatović J. Some Economic -Geographical Factors Development: The Case of Local Communities Kralje, Journal of Studies in Social Sciences, 2 (2), 2013 a, 105-133.

[14] Rajović G, Bulatović J. Geographic Favor of Analyzing Rural Space: The Case Rural Local Communities Kralje, Journal of Sustainable Development Studies, 3 (2), 2013 b, 136-167.

[15] Rajović G. Climate as the Value of Agricultural of the Example Northeastern Montenegro, American-Eurasian Journal of Agricultural \& Environmental Sciences, 12 (12), 2012, 1558-1571. 
[16] Rajović G. Evaluation og the morphometric attributes for tourism in Gornje Polimlje, Journal Natura Montenegrina, 5, 2006, 161-168.

[17] Regulation of Lima (On-line). Available from: http://www.beranetown.net (27.09.2011).

[18] Regional Business Centre Berane. Profile of Berane 1, 2122, Available from: http://www.nasme.me (07.12. 2011), 2004.

[19] Regional Business Centre Berane. Profile of Plav 1, 21-22, Available from: http://www.nasme.me (07.12. 2011), 2004.

[20] Rajović G. Structure and trends of soil usage in Montenegro, Journal Natura Montenegrina, 9(5), 2010, 205-214.

[21] Municipality Andrijevica. Content spatial and urban plan 1, 49-52, Available from: http://www.andrijevica.me (26.12.2011), 2010.

[22] Marković ĐJ. Thermal mineral water Yugoslavia, Proceedings Geographical Institute of Sciences, 1979, pp.36-37.

[23] Leko TM, Ščerbakov A, Joksimović MH. Healing waters and climate of the Kingdom of Serbs, Croats and Slovenes, the Ministry of Public Health, 1922, 26.

[24] Nikolić P. Dimitrijević D. Coal Yugoslavia, "Invention", Belgrade, 1990.

[25] Coal Mine Ivangrad. Available from: http:/ www.mans.co.me (24.12 2011).

[26] Boričić R, Lutovac MV, Petrić D. Commune Ivangrad, Workers University Ivangrad, Ivangrad, 1967.

[27] Group of author. Review of mineral resources, Federal Bureau Geo, Belgrade, 1982.

[28] Lutovac V M. Andrijevica - characteristics and geographic location factors development, Establishment Andrijevica schools and Development 1863-1973, Primary school "Bajo Jojić", Andrijevica,1973.

[29] Rajović G. Geographic View of the Industry Northeastern Montenegro with Special Emphasis on Handicrafts, Journal of Studies in Social Sciences, 4 (1) 2013c, 24-51.

[30] Todorović M. Development of modern agricultural complex in Gornji Milanovac, Proceedings of the Geographic Institute "Jovan Cvijić ", Serbian Academy of Sciences and Arts, 37, 1985, 41-78.
[31] Rajović G. Agricultural production factors intensification in North-Eastern Montenegro, Journal of Agricultural and Food Science Research, 1 (1), 2012, 11-25.

[32] Rajović G, Bulatović J. Structural changes utilization agricultural land and plant production: the case northeastern Montenegro, International Letters of Social and Humanistic Sciences, 3, $2013 \mathrm{~d}, 10-20$.

[33] Rajović G, Bulatović J. Structural changes in livestock production: the case northeastern Montenegro, International Letters of Social and Humanistic Sciences, 3, 2013c, 37-45.

[34] Rajović G. Infrastructure projects in forestry Upper Polimlja, Proceedings of abstracts, III May Conference of Strategic Management, University of Belgrade, Technical Faculty in Bor, Jagodina, on 31 May -02 June, 2007b, 43.

[35] Statistical Office of Montenegro. List of Agriculture, Podgorica, 2006.

[36] Jaćimović B. Socio-geographic transformation and land use in Ostružnica in Belgrade Sava basin, Journal of Geography Institute, 17, 1971, 217-240.

[37] Statistical Office of Montenegro. List of forest reserves in 1979, Edition Studies and Analysis, Podgorica, 1983.

[38] Statistical Office of Montenegro. List of growing stock, Podgorica, 2006.

[39] Bulatović J, Rajović G. Environmental Awareness for Sustainability: A Pilot Survey in the Belgrade Settlement Brace Jerkovic, International Journal of Advances in Management and Economics, 2 (1), 2013, 20-27.

[40] State of the economy in Plav municipality. Available from: $\mathrm{http}: / / \mathrm{www}$.gusinje-foundation.org (25.12.2011).

[41] Bulatović J, Rajović G. Market development in Gornje Polimlje and the necessity of top management introduction in function of new operations, Serbian Journal of Management, 2, 2007, 147-155.

[42] Grčić M. Problems of development and deployment of industry in the mountains of Serbia, Journal Serbian Geographical Society, 71, 1991, 57-68.

[43] Cvijanović, J. Organizational Changes, Institute of Economics, Belgrade, 2004, 7. 